\title{
Effect of Various Herbal Medicine Extracts on the Physico-chemical Properties of Emulsion-type Pork Sausage
}

\author{
Sang-Keun Jin ${ }^{1,2}$, So-Ra Ha ${ }^{1}$, Sun-Jin Hur ${ }^{3, *}$, Jung-Seok Choi ${ }^{2, *}$ \\ ${ }^{1}$ Department of Animal Resources Technology, Gyeongnam National University of Science and Technology, Jinju, Korea \\ ${ }^{2}$ Swine Science \& Technology Center, Gyeongnam National University of Science and Technology, Jinju, Korea \\ ${ }^{3}$ Department of Animal Science \& Technology, Chung-Ang University, Anseong, Korea \\ *Corresponding author: hursj@cau.ac.kr; choijs@gntech.ac.kr
}

Received April 14, 2015; Revised April 29, 2015; Accepted May 14, 2015

\begin{abstract}
The purpose of this study was to evaluate the functional properties of herbal medicine aqueous extracts as natural preservatives to improve the quality characteristics and oxidative stability of emulsion-type pork sausage. The $\mathrm{pH}$ value was significantly higher in sausages of control than in groups containing herbal medicine extracts $(p<0.05)$. The shear force values increased with the addition of herbal medicine extracts $(p<0.05)$. The addition of herbal medicine extracts also reduced the lightness and redness, and increased the yellowness, chroma, and hue observed during storage $(p<0.05)$. In addition, the anti-oxidative activity including 2-thiobarbituric acid reactive substances (TBARS), peroxide value (POV), and 2,2-diphenyl-1-picryhydrazla hydrate (DPPH) was higher in the Akebiaquinata (T3), Lonicera japonica (T4), and Chelidoniummajus (T5) groups than in the other groups $(p<0.05)$. In a sensory evaluation, the Liriopeplatyphylla (T1) and Saposhnikoviaedivaricata (T2) groups scored lower than the control, whereas the T3, T4, and T5 groups showed similar attributes compared with the control. In conclusion, the addition of herbal medicine extracts did not have negative effects on the quality of emulsion-type pork sausage, and they could be used as a natural antioxidant material to prevent lipid oxidation in meat products.
\end{abstract}

Keywords: herbal medicine extracts; emulsion-type pork sausage; antioxidant; quality characteristics

Cite This Article: Sang-Keun Jin, So-Ra Ha, Sun-Jin Hur, and Jung-Seok Choi, "Effect of Various Herbal Medicine Extracts on the Physico-chemical Properties of Emulsion-type Pork Sausage." Journal of Food and Nutrition Research, vol. 3, no. 5 (2015): 290-296. doi: 10.12691/jfnr-3-5-1.

\section{Introduction}

Shelf life extension technology in the meat product industry has been developed to include not only synthetic preservatives such as butylated hydroxytoluene (BHT), butylated hydroxyanisole (BHA), tertiary butyl hydroquinone (TBHQ), potassium sorbate, and nitrite, but also refrigeration technology [1,2]. The use of additives has been found to be as economically or qualitatively beneficial as the installation of refrigeration equipment. Recently, there has been a great interest in foods that contain natural functional components that have health benefits, because synthetic preservatives are known to demonstrate toxicity and cause disease [3,4]. A lot of research has focused on meat products containing natural additives rather than synthetic additives. For example, vitamins, herb leaf extracts, seed extracts, vegetable oils, essential oils, and other derivatives have been examined $[5,6,7]$. For some natural additives, there is little possibility of industrial application because they are less economic and more inefficient compared with synthetic additives $[8,9]$. However, herbal medicines have long been regarded as widely available and are potential sources of natural additives [10,11,12]. Traditionally, herbal medicines have been used in the treatment and prevention of diseases, and as raw food material in East Asia $[10,13]$. Consumer preference for herbal medicines as functional raw materials in medicines, food, and food additives has recently increased $[14,15,16]$. Liriope platyphylla is a widespread perennial herb occurring throughout boreal and temperate regions. It is known to affect blood glucose regulation, anticarcinogenic action, antibacterial function, anti-oxidative activity, anti-inflammatory activity, immune modulation, and liver protection $[17,18,19]$. Saposhnikovia divaricata, belonging to Apiaceae, is a perennial forage crop. Traditionally, the root and rhizome of $S$. divaricata have been used to treat inflammation, pain, sweating, and fevers, and for its antibacterial and antivirus activity in East Asia, including Korea [20,21]. Akebia quinata is a dried wild Clematis shrub that grows in mountains. It has been reported to have anti-oxidative activity, antibacterial effects, diuretic effects, and antiinflammatory activity [14,22]. Lonicera japonica, a twining shrub that grows in East Asia, including Korea, has been used as a superb anti-inflammatory medicinal plant from ancient times. It is also known to have antibacterial, antivirus, antiangiogenesis, painkiller, and liver protection effects $[23,24,25]$. Chelidonium majus is 
known worldwide for its medicinal properties, and has lately attracted interest for its anti-inflammatory, antibacterial, immune function, antitumor, liver protection, painkiller, and anticancer effects [26]. However, the effects of herbal medicine extracts on the physicochemical properties of emulsion-type sausage have not been extensively studied. Therefore, the purpose of this study was to evaluate the functional properties of the abovementioned herbal medicine extracts as natural preservatives to improve the physico-chemical and storage characteristics of emulsion-type pork sausage.

\section{Materials and Methods}

\subsection{Preparation of Herbal Medicine Extracts}

Five herbal medicines (Liriope platyphylla, Saposhnikovia divaricata, Akebia quinata, Lonicera japonica, Chelidonium majus), which were cultivated in Korea, were purchased from Kumho herbal medicine market (Seoul, Korea). The plant material was air dried at room temperature $\left(26^{\circ} \mathrm{C}\right)$ in darkness for 30 days, and was then powdered with a mill (IKA M 20, IKA, Staufen, Germany). The dried sample was extracted with distilled water $(1: 10)$ at $80{ }^{\circ} \mathrm{C}$, and was then refluxed for $6 \mathrm{~h}$ resulting in the initial extract (fraction I). The residues were extracted with distilled water $(1: 5)$ at $80^{\circ} \mathrm{C}$ for $2 \mathrm{~h}$ yielding fraction II. After cooling to room temperature and filtering (Whatman No. 2), the 2 fractions were combined and dried under a vacuum below $40^{\circ} \mathrm{C}$. Five extract types were completely dried in a freeze-drier and stored at $20^{\circ} \mathrm{C}$ until further use.

\subsection{Preparation of Emulsion-Type Pork Sausages}

Fresh lean pork and backfat was purchased from a local slaughterhouse. Subcutaneous and excessive connective tissues were removed from pork meat and ground twice through a $9-\mathrm{mm}$ plate. Seven batches (10 kg) were prepared for 3 replications and the basic recipe consisted of $66.5 \%$ meat, $15.2 \%$ back fat, and $16.4 \%$ iced water. Minced meat was ground for 1 min using a bowl cutter (Talsa K30, DSL Food Machinery Ltd., Spain). Salt (1.3\%), polyphosphate $(0.2 \%)$, and half of ice were subsequently added and mixed for $2 \mathrm{~min}$. Various herbal medicine treatments (C, no added; T1 0.2\% Liriope platyphylla; T2 0.2\% Saposhnikoviae divaricata; T3 0.2\% Akebia quinata; T4 0.2\% Lonicera japonica; T5 $0.2 \%$ Chelidonium majus) were then added. After $1 \mathrm{~min}$, the fat and spices were added and emulsified for $1 \mathrm{~min}$ and the remaining ice was added to the batter. The final emulsified batter was obtained by mixing for an additional $3 \mathrm{~min}$ at a high speed (bowl speed: 24 rpm, knife shaft speed: 2840 rpm). The temperature of the batter was maintained below $11.5^{\circ} \mathrm{C}$. The batter was then stuffed into fibrous casings (Nalo Top, Kalle GmbH, Wiesbaden, Germany; 70-mm diameter) using a stuffer (IS-8, Sirman, Italy). The stuffed samples were cooked in a heating chamber (Thematec Food Industry Co., Seongnam, Korea) to an internal temperature of $75^{\circ} \mathrm{C}$. The emulsified sausages were then cooled and stored at $4{ }^{\circ} \mathrm{C}$ for 5 weeks. The formulation for emulsified pork sausages is presented in Table 1.
Table 1. Experimental design

\begin{tabular}{lcccccc}
\hline \multirow{2}{*}{ Items $^{*}$} & \multicolumn{7}{c}{ (\%) } \\
\cline { 2 - 7 } & $\mathrm{C}$ & $\mathrm{T} 1$ & $\mathrm{~T} 2$ & $\mathrm{~T} 3$ & $\mathrm{~T} 4$ & $\mathrm{~T} 5$ \\
\hline Liriopeplatyphylla & - & 0.2 & - & - & - & - \\
Saposhnikoviaedivaricata & - & - & 0.2 & - & - & - \\
Akebiaquinata & - & - & - & 0.2 & - & - \\
Lonicera japonica & - & - & - & - & 0.2 & - \\
Chelidoniummajus & - & - & - & - & - & 0.2 \\
\hline
\end{tabular}

\subsection{Physico-chemical Analysis}

\subsection{1. pH}

$\mathrm{pH}$ was measured using a digital $\mathrm{pH}$ meter (8603, Metrohm, Herisau, Switzerland). Approximately $10 \mathrm{~g}$ of each sample was cut into small pieces and $90 \mathrm{~mL}$ of distilled water was added. A slurry was then made using a homogenizer (T25B, IKA, Staufen, Germany) and the $\mathrm{pH}$ was recorded using a $\mathrm{pH}$ meter. The $\mathrm{pH}$ meter was calibrated daily with standard buffers of pH 4.0 and 7.0 at $25{ }^{\circ} \mathrm{C}$.

\subsubsection{Shear Force $\left(\mathrm{N} / \mathrm{cm}^{2}\right)$}

Sausage samples cut into pieces $20 \mathrm{~mm}$ in length and $20 \mathrm{~mm}$ in diameter were measured using the Instron 3343 (US/MX50, A\&D Co., Norwood, Mass, U.S.A.) with a total speed of $200 \mathrm{~mm} / \mathrm{min}$, sample speed of $80 \mathrm{~m} / \mathrm{s}$, load cell of $10 \mathrm{~kg}$, and adapter area of $30 \mathrm{~mm}^{2}$.

\subsubsection{Color}

Color (International Commission on Illumination [CIE] lightness $\left[\mathrm{L}^{*}\right]$, redness $\left[\mathrm{a}^{*}\right]$, and yellowness $\left[\mathrm{b}^{*}\right]$ ) was measured using a Minolta colorimeter (CR-400, Tokyo, Japan) using a $8 \mathrm{~mm}$ aperture size, illuminant D65, a 2 ○ Closely matches CIE 1931 Standard Observer and measurement / illumination area $\Phi 8 \mathrm{~mm} / \Phi 11 \mathrm{~mm}$. The instrument was standardized using a white plate ( $Y=93.5$, $\mathrm{X}=0.3132, \mathrm{y}=0.3198$ ) and D65 illuminant source before the measurements. The chroma $\left(\mathrm{C}^{*}\right)$ and hue angle were calculated as $\left(a^{*} 2+b^{*} 2\right) 1 / 2$ and Tan-1 $\left(b^{*} / a^{*}\right)$, respectively [27]. Five readings were made for each sample, each in a different position.

\subsubsection{Peroxide Value (POV)}

The peroxide value (POV) was determined as described in the AOAC [28]. Typically, $5 \mathrm{~g}$ of sample was weighed in a $50 \mathrm{ml}$ glass tube, and to this $30 \mathrm{ml}$ of acetic acidchloroform mixture (3:2 v/v) was added. After incubation at $60^{\circ} \mathrm{C}$ for $5 \mathrm{~min}$ in a water bath, the mixture was filtered using No. 1 Whatman filter paper. Subsequently, $0.5 \mathrm{ml}$ of potassium iodide solution was added to the filtrate, which was further analyzed using an automatic titrator equipped with $\mathrm{pH}$ meter and stirrer. The titration was allowed to run against standard solution of $0.1 \mathrm{~N}$ sodium thiosulfate. POV was expressed as milliequivalent (meq) of active oxygen per kg of sausage.

\subsubsection{2-thiobarbituric Acid-reactive Substance Measurement}

The 2-thiobarbituric acid reactive substances (TBARS) level, a measure of lipid oxidation, was determined as described previously, with some modifications [29]. Briefly, $5 \mathrm{~g}$ of each sample was placed in a 50 -mL test tube and homogenized with $15 \mathrm{~mL}$ of deionized distilled 
water for $10 \mathrm{~s}$ at the highest speed. Next, $1 \mathrm{~mL}$ of sample homogenate was transferred to a disposable test tube (100 $\mathrm{mm})$, after which butylated hydroxyanisole $(50 \mu \mathrm{L}, 10 \%)$ and thiobarbituric acid/ trichloroacetic acid (TBA/TCA; 2 $\mathrm{mL}$ ) were added. The mixture was then vortexed and incubated in a boiling water bath for 15 min to develop the pink color. The sample was vortexed again and centrifuged for $15 \mathrm{~min}$ at 2,000 × g. The absorbance of the resulting supernatant solution was determined at $531 \mathrm{~nm}$ against a blank containing $1 \mathrm{~mL}$ of deionized distilled water and $2 \mathrm{~mL}$ of TBA/TCA solution. TBARS values were calculated from a standard curve of malondialdehyde (MDA), freshly prepared by acidification of TEP $(1,1,3,3-$ tetraethoxypropane) in the range of 0.02 to $0.3 \mu \mathrm{g} / \mathrm{mL}$ ( $\mathrm{y}=$ $0.8729 \mathrm{x}+0.0382, \mathrm{r}=0.9961)$ and were expressed as $\mathrm{mg}$ of malondialdehyde per $\mathrm{kg}$ of sample.

\subsubsection{Total volatile Basic Nitrogen Measurement}

Total volatile basic nitrogen (TVB-N), a measure of protein degradation, was measured using previously described methods with some modifications [30]. Briefly, $10 \mathrm{~mL}$ of each sample and a few drops of phenolphthalein indicator (0.5 wt $\%$ solution in $50 \mathrm{wt} \%$ ethanol) were placed in a distillation flask, and then $3.5 \mathrm{~mL}$ of $20 \%$ sodium hydroxide solution was added. The apparatus was immediately sealed, and the end of the steam distillate was collected in a flask containing $20 \mathrm{~mL}$ of $4 \%$ boric acid and a few drops of Tashiro indicator (methyl red/ methylene blue $=2: 1$ ). The steam distillation procedure was continued until $250 \mathrm{~mL}$ of distillate was collected. Next, the obtained basic solution was titrated against 0.01-M hydrochloric acid to the end point, which was indicated by a green to gray color change. The VBN content was determined after blank correction that was determined by the steam distillation of $6 \%$ perchloric acid.

\subsubsection{2,2-diphenyl-1-picryhydrazla Hydrate (DPPH) Radical Scavenging Activity}

The 2,2-diphenyl-1-picryhydrazla hydrate (DPPH) radical scavenging activity was measured according to the method of Pearson [31] with some modifications. Each peptide fraction $(500 \mu \mathrm{L})$ was mixed with $500 \mu \mathrm{L}$ of ethanol and $250 \mu \mathrm{L}$ of a DPPH solution $(0.5 \mathrm{mM} 1,1-$ diphenyl-2-picrylhydrazyl/ethanol). The mixtures were incubated for $30 \mathrm{~min}$ in the dark at room temperature and the reduction of DPPH radicals was measured at $517 \mathrm{~nm}$. DPPH radical scavenging activity was calculated as: DPPH radical scavenging activity $(\%)=($ [absorption of control-absorption of sample]/absorption of control) $\times 100$. The control was analyzed in the same manner, but distilled water was used instead of samples.

\subsection{Sensory Evaluation}

A sensory evaluation was performed by a panel of 15 trained tasters. Panel development followed the prescreening, screening, training, and performance evaluation phases as described previously [32]. The panel evaluated each treatment for each replication in triplicate, and the evaluation was performed with the samples at room temperature. Triplicate responses were taken to monitor the inherent texture variability associated with the samples. One slice, $1 \mathrm{~cm}$ in thickness and $1.8 \mathrm{~cm}$ in diameter, was cut into 6 pie-shaped wedges and presented to each panelist. The panelists chose 3 of the most characteristic wedges to avoid samples containing large pieces of connective tissue. The sausage color and flavor ( 1 = extremely undesirable, 9 = extremely desirable), juiciness ( 1 = extremely dry, $9=$ extremely juicy), and overall acceptability $(1=$ extremely undesirable, $9=$ extremely desirable) were evaluated using a 9-point scale.

\subsection{Statistical Analysis}

The entire experiment was replicated three times at different times in the same place, and a completely randomized design was used. The data of physicochemical properties of sausages during storage were analyzed by an analysis of variance (one-way ANOVA) using the GLM procedure of SAS program [33], which considered addition of extracts as a fixed effect, and replicate as a random term. Duncan's multiple range test was used to determine the statistical significance of differences among the means at a 95\% significance level. Mean values and standard deviations were reported. All data analysis was performed using SAS for Windows, version 9.3 (SAS Institute Inc., Cary, N.C., U.S.A.).

\section{Results and Discussion}

\subsection{Quality Characteristics}

The effects of the herbal medicine extracts on the $\mathrm{pH}$ and shear force of emulsion-type pork sausage are presented in Table 2. The $\mathrm{pH}$ of sausages in the control group was significantly higher than that of the treatment groups when stored at $4^{\circ} \mathrm{C}$ for 5 weeks $(p<0.05)$. Significant differences were observed among the treatment groups, but the $\mathrm{pH}$ values ranged from 5.88 to 5.99. In addition, all of the $\mathrm{pH}$ values increased as the storage time increased. The shear force values of the emulsion-type pork sausage were significantly increased by the addition of herbal medicine extracts after 3 weeks of storage, but those of T1 and T2 were decreased after 5 weeks $(p<0.05)$. The VBN values were significantly higher in the herbal medicine extracts groups than in the control during storage $(p<0.05)$. However, all treatment groups showed VBN levels within the edible range during the 5-week period.

Herbal medicine extracts contain a lot of phenolic acids such as benzoic acids and cinnamic acids [34,35]. It was determined that these acids caused the decrease in the $\mathrm{pH}$ of the sausages containing herbal medicine extracts. In general, the $\mathrm{pH}$ of meat products decreases with increased storage owing to the growth of lactic bacteria [36]. Increased $\mathrm{pH}$ is also related to a decrease in electrolyte dissociation and/or increase in the concentration of buffering proteins, as well as to the formation of ammonia [37]. According to Lim et al. [38], 1.0-2.0\% water extract of Akebia quinata activated the growth of Bifidobacterium. Although the lactic bacteria counts are not shown in the present study, the addition of $0.2 \%$ herbal medicine extracts had a slight effect on the growth of lactic bacteria in the emulsion-type pork sausage during storage. In addition, according to the report of Han and Rhee [39], the $\mathrm{pH}$ values of herb extracts (white peony, red peony, rehmannia, moutan peony, angelica, rosemary) ranged from 3.05 to 3.88. Generally, the $\mathrm{pH}$ of meat products has 
a significant influence on the binding capacity of major meat components such as water, protein, and fat [40,41]. Moreover, the shear force value is influenced by binding capacity. Thus, it was thought that the shear force values in emulsion-type pork sausages with herbal medicine extracts were higher than those of control samples during cold storage periods.

Table 2. Effect of herbal medicine extracts on quality properties of emulsion-type pork sausages during 5 weeks at $10^{\circ} \mathrm{C}$

\begin{tabular}{|c|c|c|c|c|}
\hline \multirow{2}{*}{ Items } & \multirow{2}{*}{ Treatments ${ }^{1)}$} & \multicolumn{3}{|c|}{ Storage (weeks) } \\
\hline & & 0 & 3 & 5 \\
\hline \multirow{6}{*}{$\mathrm{pH}$} & C & $5.98 \pm 0.01^{\mathrm{Ab}}$ & $6.06 \pm 0.01^{\mathrm{Aa}}$ & $6.05 \pm 0.01^{\mathrm{Aa}}$ \\
\hline & $\mathrm{T} 1$ & $5.88 \pm 0.02^{\mathrm{Bc}}$ & $5.95 \pm 0.01^{\mathrm{Bb}}$ & $5.99 \pm 0.01^{\mathrm{Ba}}$ \\
\hline & $\mathrm{T} 2$ & $5.89 \pm 0.00^{\mathrm{Bc}}$ & $5.94 \pm 0.01^{\mathrm{BCb}}$ & $5.96 \pm 0.01^{\mathrm{Da}}$ \\
\hline & T3 & $5.88 \pm 0.01^{\mathrm{Bb}}$ & $5.95 \pm 0.03^{\mathrm{Ba}}$ & $5.96 \pm 0.01^{\mathrm{Da}}$ \\
\hline & $\mathrm{T} 4$ & $5.89 \pm 0.01^{\mathrm{Bc}}$ & $5.94 \pm 0.02^{\mathrm{BCb}}$ & $5.98 \pm 0.00^{\mathrm{BCa}}$ \\
\hline & T5 & $5.89 \pm 0.01^{\mathrm{Bc}}$ & $5.92 \pm 0.00^{\mathrm{Cb}}$ & $5.97 \pm 0.00^{\mathrm{CDa}}$ \\
\hline \multirow{6}{*}{$\begin{array}{l}\text { Shear } \\
\text { force } \\
\left(\mathrm{N} / \mathrm{cm}^{2}\right)\end{array}$} & C & $4.01 \pm 1.17^{\mathrm{Cc}}$ & $11.95 \pm 0.49^{\mathrm{Bb}}$ & $16.56 \pm 0.88^{\mathrm{Aa}}$ \\
\hline & $\mathrm{T} 1$ & $4.31 \pm 0.29^{\mathrm{BCc}}$ & $12.25 \pm 0.58^{\mathrm{ABa}}$ & $11.27 \pm 0.39^{\mathrm{Cb}}$ \\
\hline & $\mathrm{T} 2$ & $4.41 \pm 0.68^{\mathrm{BCb}}$ & $12.25 \pm 0.49^{\mathrm{ABa}}$ & $12.05 \pm 0.39^{\mathrm{Ca}}$ \\
\hline & T3 & $5.68 \pm 0.09^{\mathrm{Ac}}$ & $12.93 \pm 0.29^{\mathrm{Ab}}$ & $15.68 \pm 0.39^{\mathrm{ABa}}$ \\
\hline & $\mathrm{T} 4$ & $5.29 \pm 0.19^{\mathrm{ABC}}$ & $12.44 \pm 0.09^{\mathrm{ABb}}$ & $14.79 \pm 0.68^{\mathrm{Ba}}$ \\
\hline & $\mathrm{T} 5$ & $4.60 \pm 0.19^{\mathrm{BCc}}$ & $12.15 \pm 0.39^{\mathrm{ABb}}$ & $15.48 \pm 0.58^{\mathrm{ABa}}$ \\
\hline \multirow{6}{*}{$\begin{array}{l}\text { VBN } \\
\text { (mg\%) }\end{array}$} & $\mathrm{C}$ & $6.07 \pm 0.16^{\mathrm{Dc}}$ & $6.44 \pm 0.00^{\mathrm{Db}}$ & $6.74 \pm 0.16^{\mathrm{Ca}}$ \\
\hline & $\mathrm{T} 1$ & $7.65 \pm 0.16^{\mathrm{BCb}}$ & $7.70 \pm 0.14^{\mathrm{BCb}}$ & $8.10 \pm 0.08^{\mathrm{Aa}}$ \\
\hline & $\mathrm{T} 2$ & $8.17 \pm 0.08^{\mathrm{A}}$ & $8.21 \pm 0.16^{A}$ & $8.00 \pm 0.08^{\mathrm{AB}}$ \\
\hline & T3 & $7.47 \pm 0.16^{\mathrm{Cb}}$ & $7.51 \pm 0.08^{\mathrm{Cb}}$ & $8.00 \pm 0.08^{\mathrm{ABa}}$ \\
\hline & $\mathrm{T} 4$ & $7.89 \pm 0.21^{\mathrm{AB}}$ & $7.89 \pm 0.16^{\mathrm{B}}$ & $8.00 \pm 0.08^{\mathrm{AB}}$ \\
\hline & $\mathrm{T} 5$ & $7.51 \pm 0.29^{\mathrm{C}}$ & $7.51 \pm 0.08^{\mathrm{C}}$ & $7.82 \pm 0.08^{\mathrm{B}}$ \\
\hline
\end{tabular}

${ }^{\mathrm{a}-\mathrm{b}}$ Means \pm SD with different superscription within the same row differ $(p<0.05)$.

${ }_{A-E}$ Means \pm SD with different superscription within the same column differ $(p<0.05)$.

\subsection{Sausage Color}

The effect of herbal medicine extracts on the CIE ${ }^{*}$ color of the emulsion-type pork sausage is presented in Table 3. The $\mathrm{L}^{*}$ value was significantly lower in the T4 and T5 groups than in the other groups during all storage periods $(p<0.05)$. Redness $\left(\mathrm{a}^{*}\right)$ values were higher in the control than in the groups with added herbal medicine extracts at 0 and 3 weeks $(p<0.05)$, and the redness values of the T3, $\mathrm{T} 4$, and $\mathrm{T} 5$ groups were significantly lower than those of the other groups after 3 weeks $(p<0.05)$. The $\mathrm{b}^{*}$ values were significantly higher in the $\mathrm{T} 3, \mathrm{~T} 4$, and $\mathrm{T} 5$ groups than in the other groups during all cold storage periods $(p<0.05)$. Chroma (C) and hue (h) values of the emulsiontype pork sausage were significantly higher in all treatment groups containing herbal medicine extracts than in the control $(p<0.05)$. A comparison between the treatment groups revealed that those of the T4 and T5 groups were significantly higher than those of the T1, T2, and T3 groups during cold storage $(p<0.05)$. Yang et al. [42] reported that the lightness of pork sausage containing green tea extract was lower than that of the control, and the lightness decreased as of the amount of green tea extract added increased. Green tea extract has been found to contain many polyphenolic flavonoids [43], and this was further confirmed by Bozkurt [44]. Herbal medicine extracts also contain many flavonoids, including catechin hydrate, gallocatechin, epicatechin, and epigallocatechin, which contribute to the yellow coloration of the plants $[35,36,45,46]$. Therefore, this was considered to contribute to the increase in yellowness as well as chroma and hue values in the emulsion-type pork sausage, while the redness was decreased.

Table 3. Effect of herbal medicine extracts on CIE* color of emulsion-type pork sausages during 5 weeks at $10^{\circ} \mathrm{C}$

\begin{tabular}{|c|c|c|c|c|}
\hline \multirow{2}{*}{ Items } & \multirow{2}{*}{ Treatments $^{1)}$} & \multicolumn{3}{|c|}{ Storage (weeks) } \\
\hline & & 0 & 3 & 5 \\
\hline \multirow{6}{*}{$\mathrm{L}^{*}$} & C & $75.62 \pm 0.58^{\mathrm{A}}$ & $75.88 \pm 0.21^{\mathrm{A}}$ & $76.19 \pm 0.21^{\mathrm{A}}$ \\
\hline & $\mathrm{T} 1$ & $75.78 \pm 0.36^{\mathrm{A}}$ & $75.75 \pm 0.48^{\mathrm{A}}$ & $75.87 \pm 0.43 \mathrm{~A}^{\mathrm{B}}$ \\
\hline & $\mathrm{T} 2$ & $75.84 \pm 0.46^{\mathrm{A}}$ & $75.49 \pm 0.84^{\mathrm{A}}$ & $75.39 \pm 0.23^{\mathrm{B}}$ \\
\hline & $\mathrm{T} 3$ & $75.52 \pm 0.67^{\mathrm{A}}$ & $75.53 \pm 0.81^{\mathrm{A}}$ & $76.11 \pm 0.30^{\mathrm{A}}$ \\
\hline & $\mathrm{T} 4$ & $72.91 \pm 0.79^{\mathrm{B}}$ & $73.14 \pm 0.46^{\mathrm{B}}$ & $73.51 \pm 0.35^{\mathrm{C}}$ \\
\hline & T5 & $74.00 \pm 0.71^{\mathrm{B}}$ & $73.83 \pm 0.33^{\mathrm{B}}$ & $73.88 \pm 0.38^{\mathrm{C}}$ \\
\hline \multirow{6}{*}{$a^{*}$} & $\mathrm{C}$ & $2.53 \pm 0.11^{\mathrm{A}}$ & $2.34 \pm 0.25^{\mathrm{A}}$ & $2.47 \pm 0.28^{\mathrm{A}}$ \\
\hline & $\mathrm{T} 1$ & $2.40 \pm 0.12^{\mathrm{Aa}}$ & $1.74 \pm 0.27^{\mathrm{Bb}}$ & $2.03 \pm 0.25^{\mathrm{Bab}}$ \\
\hline & $\mathrm{T} 2$ & $1.66 \pm 0.32^{\mathrm{B}}$ & $1.76 \pm 0.50^{\mathrm{B}}$ & $2.15 \pm 0.22^{\mathrm{AB}}$ \\
\hline & T3 & $1.32 \pm 0.34^{\mathrm{B}}$ & $0.88 \pm 0.31^{\mathrm{C}}$ & $0.74 \pm 0.17^{\mathrm{C}}$ \\
\hline & $\mathrm{T} 4$ & $1.36 \pm 0.30^{\mathrm{B}}$ & $1.07 \pm 0.11^{\mathrm{C}}$ & $0.99 \pm 0.13^{\mathrm{C}}$ \\
\hline & $\mathrm{T} 5$ & $1.56 \pm 0.23^{\mathrm{Ba}}$ & $1.02 \pm 0.13^{\mathrm{Cb}}$ & $0.72 \pm 0.04^{\mathrm{Cb}}$ \\
\hline \multirow{6}{*}{$b^{*}$} & $\mathrm{C}$ & $8.66 \pm 0.03^{E}$ & $9.07 \pm 0.46^{\mathrm{D}}$ & $9.16 \pm 0.19^{\mathrm{E}}$ \\
\hline & $\mathrm{T} 1$ & $9.25 \pm 0.12^{\mathrm{Db}}$ & $10.17 \pm 0.39^{\mathrm{Ca}}$ & $10.05 \pm 0.19^{\mathrm{Da}}$ \\
\hline & $\mathrm{T} 2$ & $10.20 \pm 0.17^{\mathrm{C}}$ & $10.53 \pm 0.43^{\mathrm{BC}}$ & $10.37 \pm 0.34^{\mathrm{D}}$ \\
\hline & $\mathrm{T} 3$ & $10.64 \pm 0.30^{\text {В }}$ & $11.02 \pm 0.22^{\mathrm{B}}$ & $11.27 \pm 0.27^{\mathrm{C}}$ \\
\hline & $\mathrm{T} 4$ & $12.08 \pm 0.10^{\mathrm{A}}$ & $12.04 \pm 0.30^{\mathrm{A}}$ & $12.17 \pm 0.29^{\mathrm{B}}$ \\
\hline & T5 & $12.03 \pm 0.30^{\mathrm{Ac}}$ & $12.50 \pm 0.07^{\mathrm{Ab}}$ & $13.03 \pm 0.05^{\mathrm{Aa}}$ \\
\hline \multirow{6}{*}{ C } & C & $9.97 \pm 0.04^{\mathrm{E}}$ & $10.35 \pm 0.47^{\mathrm{D}}$ & $10.47 \pm 0.16^{\mathrm{E}}$ \\
\hline & $\mathrm{T} 1$ & $10.58 \pm 0.15^{\mathrm{Db}}$ & $11.49 \pm 0.36^{\mathrm{Ca}}$ & $11.44 \pm 0.19^{\mathrm{Da}}$ \\
\hline & $\mathrm{T} 2$ & $11.55 \pm 0.19^{\mathrm{C}}$ & $11.96 \pm 0.37^{\mathrm{BC}}$ & $11.86 \pm 0.35^{\mathrm{D}}$ \\
\hline & $\mathrm{T} 3$ & $12.05 \pm 0.27^{\mathrm{B}}$ & $12.46 \pm 0.19^{\mathrm{B}}$ & $12.71 \pm 0.31^{\mathrm{C}}$ \\
\hline & $\mathrm{T} 4$ & $14.02 \pm 0.04^{\mathrm{A}}$ & $13.92 \pm 0.32^{\mathrm{A}}$ & $14.04 \pm 0.33^{\mathrm{B}}$ \\
\hline & $\mathrm{T} 5$ & $13.89 \pm 0.30^{\mathrm{Ac}}$ & $14.42 \pm 0.11^{\mathrm{Ab}}$ & $15.16 \pm 0.18^{\mathrm{Aa}}$ \\
\hline \multirow{6}{*}{ h } & C & $73.70 \pm 2.08^{\mathrm{B}}$ & $76.33 \pm 2.09^{\mathrm{D}}$ & $75.82 \pm 1.78^{\mathrm{C}}$ \\
\hline & $\mathrm{T} 1$ & $76.37 \pm 0.71^{\mathrm{Bb}}$ & $80.81 \pm 1.57^{\mathrm{Ca}}$ & $79.31 \pm 1.40^{\mathrm{Ba}}$ \\
\hline & $\mathrm{T} 2$ & $81.36 \pm 1.75^{\text {Aab }}$ & $83.13 \pm 1.21^{\mathrm{BCa}}$ & $79.08 \pm 1.44^{\mathrm{Bb}}$ \\
\hline & T3 & $83.38 \pm 1.89^{\mathrm{A}}$ & $85.77 \pm 1.56^{\mathrm{A}}$ & $86.51 \pm 0.89^{\mathrm{A}}$ \\
\hline & $\mathrm{T} 4$ & $84.11 \pm 1.34^{\mathrm{A}}$ & $85.36 \pm 0.58^{\mathrm{AB}}$ & $85.74 \pm 0.64^{\mathrm{A}}$ \\
\hline & T5 & $83.22 \pm 1.16^{\mathrm{Ac}}$ & $85.74 \pm 0.51^{\mathrm{Ab}}$ & $87.30 \pm 0.41^{\text {Aa }}$ \\
\hline
\end{tabular}

${ }_{\mathrm{a}-\mathrm{b}}$ Means \pm SD with different superscript letters within the same row differ $(p<0.05)$.

A-E Means \pm SD with different superscript letters within the same column differ $(p<0.05)$.

${ }^{*} \mathrm{~L}$ : lightness, a: redness, b: yellowness

C: chroma, h: hue value.

\subsection{Antioxidant Activity}

The antioxidant effects of herbal medicine extracts added to the emulsion-type pork sausage are presented in Table 4. TBARS values were significantly lower in the T3, $\mathrm{T} 4$, and T5 groups during 5 weeks of storage $(p<0.05)$, and the T2 group had the highest value. In a comparison of the POV values, significant differences among groups were observed during all storage periods. Groups with added herbal medicine extracts showed lower POV values than the control $(p<0.05)$. In particular, those of the T3, $\mathrm{T} 4$, and T5 groups were significantly lower than the other groups after 5 weeks of storage. The DPPH free radical scavenging activity was also significantly higher in the T3, $\mathrm{T} 4$, and $\mathrm{T} 5$ groups than in the other groups during storage $(p<0.05)$, while T1 and T2 did not differ significantly in 
DPPH free radical scavenging activity compared with the control. Numerous studies have reported that plantderived ingredients possess anti-oxidative ability to prevent lipid oxidation in meat products $[2,6,47,48,49]$. According to the report of Park et al. [35,36], the total contents of phenolic and flavonoid materials in the 5 herbal medicine extracts examined were $25.78 \mathrm{mg}$ and 459.86 in Liriopepla typhylla, 2,453 and 5,105 in A. quinata, 1,369 and 1,708 in S. divaricata, 5,041 and 71,023 in Lonicera japonica, and 2,135 and 3,884 in C. majus, (mg/100 g), respectively. It was indicated that the extracts from these herbal medicines have the capacity to scavenge free radicals. The decrease in TBA and POV as well as the increase in DPPH, lipid oxidation indicators, were probably due to the presence of herbal medicine extracts, which have been reported to have antioxidative ability and to retard fat oxidation. Numerous studies have reported that phytochemicals such as phenolic compounds have a major contribution to antioxidant activity. In general, free radical scavenging and antioxidant activity of phenols (for example, flavonoids and phenolic acids) mainly depends on the number and position of hydrogendonating hydroxyl groups on the aromatic ring of the phenolic molecules, and is also affected by other factors such as glycosylation of aglycones and additional $\mathrm{H}$ donating groups (-NH, -SH) [50]. Phenolic compounds serve as antioxidants by donating hydrogen atoms to radical species, and are oxidized to phenoxyl radicals themselves [51]. Therefore, the prevention of lipid oxidation by breaking radical reaction chains is considered the most important antioxidant effect of herbal medicine extracts in sausage samples because they contain flavonoid or phenolic components, which might be responsible for the apparent antioxidative activity. In summary, the addition of the phenol-rich herbal medicine extracts could inhibit the formation of secondary lipid oxidation products and improve the shelf life of sausage.

Table 4. Effect of herbal medicine extracts on anti-oxidative activity of emulsion-type pork sausages during 5 weeks at $10^{\circ} \mathrm{C}$

\begin{tabular}{|c|c|c|c|c|}
\hline \multirow{2}{*}{ Items } & \multirow{2}{*}{ Treatments $^{1)}$} & \multicolumn{3}{|c|}{ Storage (weeks) } \\
\hline & & 0 & 3 & 5 \\
\hline \multirow{6}{*}{$\begin{array}{c}\text { TBARS } \\
(\mathrm{mg} \\
\mathrm{MDA} / \mathrm{kg})\end{array}$} & $\mathrm{C}$ & $0.42 \pm 0.02^{\mathrm{BCC}}$ & $0.65 \pm 0.00^{\mathrm{Ba}}$ & $0.56 \pm 0.03^{\mathrm{Bb}}$ \\
\hline & $\mathrm{T} 1$ & $0.48 \pm 0.05^{\mathrm{ABb}}$ & $0.61 \pm 0.03^{\mathrm{Ba}}$ & $0.58 \pm 0.01^{\mathrm{Ba}}$ \\
\hline & $\mathrm{T} 2$ & $0.51 \pm 0.04^{\mathrm{Ab}}$ & $0.74 \pm 0.02^{\mathrm{Aa}}$ & $0.78 \pm 0.01^{\mathrm{Aa}}$ \\
\hline & T3 & $0.45 \pm 0.02^{\mathrm{BCb}}$ & $0.55 \pm 0.05^{\text {Ca }}$ & $0.48 \pm 0.01^{\mathrm{Cb}}$ \\
\hline & $\mathrm{T} 4$ & $0.39 \pm 0.03^{\mathrm{Cb}}$ & $0.50 \pm 0.02^{\mathrm{Ca}}$ & $0.35 \pm 0.01^{\mathrm{Db}}$ \\
\hline & $\mathrm{T} 5$ & $0.39 \pm 0.02^{\mathrm{Ca}}$ & $0.41 \pm 0.04^{\mathrm{Da}}$ & $0.33 \pm 0.02^{\mathrm{Db}}$ \\
\hline \multirow{6}{*}{$\begin{array}{c}\mathrm{POV} \\
\text { (meq/kg) }\end{array}$} & C & $1.39 \pm 0.07^{\mathrm{Ac}}$ & $1.88 \pm 0.11^{\mathrm{Ab}}$ & $2.10 \pm 0.10^{\mathrm{Aa}}$ \\
\hline & $\mathrm{T} 1$ & $1.37 \pm 0.04^{\mathrm{Ac}}$ & $1.63 \pm 0.05^{\mathrm{Bb}}$ & $2.09 \pm 0.04^{\mathrm{Aa}}$ \\
\hline & $\mathrm{T} 2$ & $1.31 \pm 0.16^{\mathrm{ABC}}$ & $1.64 \pm 0.01^{\mathrm{Bb}}$ & $2.06 \pm 0.05^{\mathrm{Aa}}$ \\
\hline & T3 & $1.24 \pm 0.05^{\mathrm{Bb}}$ & $1.63 \pm 0.02^{\mathrm{Ba}}$ & $1.72 \pm 0.11^{\mathrm{Ba}}$ \\
\hline & $\mathrm{T} 4$ & $1.21 \pm 0.03^{\mathrm{B}}$ & $1.27 \pm 0.10^{\mathrm{C}}$ & $1.35 \pm 0.09^{\mathrm{C}}$ \\
\hline & $\mathrm{T} 5$ & $1.00 \pm 0.00^{\mathrm{Cc}}$ & $1.59 \pm 0.01^{\mathrm{Bb}}$ & $1.61 \pm 0.01^{\mathrm{Ba}}$ \\
\hline \multirow{6}{*}{$\begin{array}{c}\text { DPPH } \\
(\%)\end{array}$} & C & $16.40 \pm 0.79^{\mathrm{Ca}}$ & $16.32 \pm 0.90^{\mathrm{Da}}$ & $9.82 \pm 0.75^{\mathrm{Db}}$ \\
\hline & $\mathrm{T} 1$ & $15.34 \pm 0.55^{\mathrm{Ca}}$ & $13.79 \pm 0.66^{\mathrm{Eab}}$ & $12.66 \pm 1.16^{\mathrm{Cb}}$ \\
\hline & $\mathrm{T} 2$ & $16.23 \pm 0.71^{\mathrm{Ca}}$ & $10.74 \pm 0.51^{\mathrm{Fb}}$ & $9.69 \pm 0.87^{\mathrm{Db}}$ \\
\hline & T3 & $29.17 \pm 1.00^{\mathrm{Bb}}$ & $31.66 \pm 0.90^{\mathrm{Aa}}$ & $27.59 \pm 0.60^{\mathrm{Bt}}$ \\
\hline & $\mathrm{T} 4$ & $35.53 \pm 0.78^{\mathrm{Aa}}$ & $28.33 \pm 1.04^{\mathrm{Bb}}$ & $27.05 \pm 1.10^{\mathrm{Bb}}$ \\
\hline & $\mathrm{T} 5$ & $30.06 \pm 1.45^{\mathrm{Ba}}$ & $22.93 \pm 0.81^{\mathrm{Cb}}$ & $30.53 \pm 1.19^{\mathrm{A}_{\mathrm{C}}}$ \\
\hline
\end{tabular}

${ }^{\mathrm{a}-\mathrm{b}}$ Means \pm SD with different superscript letters within the same row differ $(p<0.05)$.

${ }^{\text {A-F }}$ Means \pm SD with different superscript letters within the same column differ $(p<0.05)$.

\subsection{Sensory Evaluation}

Table 5 shows the effects of herbal medicine extracts on the sensory evaluation of emulsion-type pork sausage during cold storage. At week 0 , the T4 and T5 groups scored significantly lower in subjective color than the other groups $(p<0.05)$. After 3 weeks, the control retained higher color scores than the groups with added herbal medicine extracts. In addition, the flavor scores for the T1 and $\mathrm{T} 2$ groups were lower than for the other groups during cold storage. With respect to the juiciness and overall acceptability, there were significant differences among the treatments. T1 and T2 scored lower in juiciness and overall acceptability than the other groups during cold storage $(p<0.05)$. In general, antioxidants could prevent changes in lipids. However, the antioxidants from plantderivatives should be used in a range that does not change the taste of foods. Muthukumar et al.[52] reported that the addition of 600 ppm of phenolics from Moringa oleifera leaves to raw and cooked pork patties did not affect the sensory attributes. In addition, sensory attributes including tenderness, juiciness, overall texture, and flavor were not affected by the addition of plant extracts [53], while the anti-oxidative activity of plant extracts confers stability to fat oxidation in meat products during storage [16]. Therefore, rancid flavors or off-odors could be reduced by the addition of herbal medicine extracts to meat products relative to meat products without the addition during storage. However, according to a report by Kim [54], a sensory evaluation using a water extract from Liriope platyphylla showed a pale-yellow, non-bitter, and astringent taste with low overall acceptability.

Table 5. Effect of herbal medicine extracts on sensory evaluation of emulsion-type pork sausages during 5 weeks at $10^{\circ} \mathrm{C}$

\begin{tabular}{|c|c|c|c|c|}
\hline \multirow{2}{*}{ Items } & \multirow{2}{*}{ Treatments $^{1)}$} & \multicolumn{3}{|c|}{ Storage (weeks) } \\
\hline & & 0 & 3 & 5 \\
\hline \multirow{6}{*}{ Color } & $\mathrm{C}$ & $8.00 \pm 0.35^{\mathrm{A}}$ & $7.67 \pm 0.41^{\mathrm{A}}$ & $7.50 \pm 0.50^{\mathrm{A}}$ \\
\hline & $\mathrm{T} 1$ & $7.30 \pm 0.45^{\mathrm{BC}}$ & $6.70 \pm 0.45^{\mathrm{B}}$ & $6.70 \pm 0.45^{\mathrm{B}}$ \\
\hline & $\mathrm{T} 2$ & $7.40 \pm 0.55^{\mathrm{AB}}$ & $6.83 \pm 0.26^{\mathrm{B}}$ & $6.80 \pm 0.57^{\mathrm{AB}}$ \\
\hline & T3 & $7.40 \pm 0.42^{\mathrm{ABa}}$ & $6.67 \pm 0.41^{\mathrm{Bb}}$ & $6.70 \pm 0.45^{\mathrm{Bb}}$ \\
\hline & $\mathrm{T} 4$ & $6.70 \pm 0.57^{\mathrm{CD}}$ & $6.42 \pm 0.38^{\mathrm{B}}$ & $6.80 \pm 0.57^{\mathrm{AB}}$ \\
\hline & T5 & $6.30 \pm 0.45^{\mathrm{D}}$ & $6.50 \pm 0.32^{\mathrm{B}}$ & $6.90 \pm 0.42^{\mathrm{AB}}$ \\
\hline \multirow{6}{*}{ Flavor } & $\mathrm{C}$ & $7.60 \pm 0.42^{\mathrm{A}}$ & $7.25 \pm 0.69^{\mathrm{A}}$ & $7.10 \pm 0.65^{\mathrm{BC}}$ \\
\hline & $\mathrm{T} 1$ & $7.00 \pm 0.35^{\mathrm{ABa}}$ & $6.40 \pm 0.22^{\mathrm{Bb}}$ & $6.80 \pm 0.27^{\mathrm{CDa}}$ \\
\hline & $\mathrm{T} 2$ & $6.50 \pm 0.61^{\mathrm{B}}$ & $6.42 \pm 0.38^{\mathrm{B}}$ & $6.20 \pm 0.27^{\mathrm{D}}$ \\
\hline & T3 & $7.20 \pm 0.27^{\mathrm{AB}}$ & $7.58 \pm 0.58^{\mathrm{A}}$ & $7.90 \pm 0.65^{\mathrm{A}}$ \\
\hline & $\mathrm{T} 4$ & $7.10 \pm 0.55^{\mathrm{AB}}$ & $7.17 \pm 0.52^{\mathrm{A}}$ & $7.10 \pm 0.65^{\mathrm{BC}}$ \\
\hline & T5 & $7.20 \pm 0.76^{\mathrm{AB}}$ & $7.33 \pm 0.52^{\mathrm{A}}$ & $7.80 \pm 0.57^{\mathrm{AB}}$ \\
\hline \multirow{6}{*}{ Juiciness } & $\mathrm{C}$ & $7.90 \pm 0.42^{\mathrm{A}}$ & $7.50 \pm 0.55^{\mathrm{A}}$ & $7.40 \pm 0.42^{\mathrm{A}}$ \\
\hline & $\mathrm{T} 1$ & $7.00 \pm 0.35^{\mathrm{B}}$ & $6.70 \pm 0.27^{\mathrm{BC}}$ & $7.10 \pm 0.74^{\mathrm{AB}}$ \\
\hline & $\mathrm{T} 2$ & $6.90 \pm 0.65^{\mathrm{B}}$ & $6.67 \pm 0.68^{\mathrm{C}}$ & $6.40 \pm 0.42^{\mathrm{B}}$ \\
\hline & T3 & $7.10 \pm 0.22^{\mathrm{B}}$ & $7.33 \pm 0.52^{\mathrm{AB}}$ & $7.60 \pm 0.65^{\mathrm{A}}$ \\
\hline & $\mathrm{T} 4$ & $7.00 \pm 0.35^{\mathrm{B}}$ & $7.33 \pm 0.41^{\mathrm{AB}}$ & $7.20 \pm 0.57^{\mathrm{A}}$ \\
\hline & $\mathrm{T} 5$ & $7.20 \pm 0.27^{\mathrm{B}}$ & $7.42 \pm 0.20^{\mathrm{AB}}$ & $7.30 \pm 0.45^{\mathrm{A}}$ \\
\hline \multirow{6}{*}{$\begin{array}{c}\text { Overall } \\
\text { acceptability }\end{array}$} & $\mathrm{C}$ & $7.60 \pm 0.22^{\mathrm{A}}$ & $7.33 \pm 0.41^{\mathrm{AB}}$ & $7.30 \pm 0.45^{\mathrm{AB}}$ \\
\hline & $\mathrm{T} 1$ & $7.00 \pm 0.35^{\mathrm{B}}$ & $6.60 \pm 0.22^{\mathrm{C}}$ & $7.00 \pm 0.50^{\mathrm{ABC}}$ \\
\hline & $\mathrm{T} 2$ & $6.80 \pm 0.57^{\mathrm{B}}$ & $6.83 \pm 0.61^{\mathrm{BC}}$ & $6.40 \pm 0.42^{\mathrm{C}}$ \\
\hline & T3 & $7.10 \pm 0.42^{\mathrm{AB}}$ & $7.33 \pm 0.75^{\mathrm{AB}}$ & $7.50 \pm 0.61^{\mathrm{AB}}$ \\
\hline & $\mathrm{T} 4$ & $6.90 \pm 0.42^{\text {B }}$ & $6.83 \pm 0.61^{\mathrm{BC}}$ & $6.90 \pm 0.42^{\mathrm{BC}}$ \\
\hline & T5 & $6.90 \pm 0.42^{\mathrm{Bb}}$ & $7.50 \pm 0.00^{\mathrm{Aa}}$ & $7.60 \pm 0.22^{\mathrm{Aa}}$ \\
\hline
\end{tabular}

$\mathrm{a}-\mathrm{b}$ Means \pm SD with different superscript letters within the same row differ $(p<0.05)$.

A-D Means \pm SD with different superscript letters within the same column differ $(p<0.05)$.

1 : very bad or poor, 9 : very good or superb 


\section{Conclusions}

This study was conducted to evaluate the effects of the extracts of 5 herbal medicines on the physico-chemical properties of emulsion-type pork sausage during cold storage. The $\mathrm{pH}$ was significantly higher in the control than in groups containing the herbal medicine extracts $(p<0.05)$. An increase in shear force owing to the addition of herbal medicine extracts was observed $(p<0.05)$. The addition of the herbal medicine extracts also reduced the lightness and redness, while increasing the yellowness, chroma, and hue during storage $(p<0.05)$. In addition, the antioxidant activity, as measured by TBARS, POV, and $\mathrm{DPPH}$, was higher in the T3, T4, and T5 groups than in the other groups $(p<0.05)$. In a sensory evaluation, the T1 and T2 groups were given lower scores, and the T3, T4, and $\mathrm{T} 5$ groups showed similar attributes relative to the control. In conclusion, the addition of herbal medicine extracts did not have negative effects on the physicochemical properties of emulsion-type pork sausage, and they could be used as natural antioxidant materials to prevent lipid oxidation in meat products.

\section{Acknowledgments}

This work was carried out with the support of the "Cooperative Research Program for Agriculture, Science, \& Technology Development (Project title: Development of Manuals for Manufacturing and Hygienic Management of Meat Products for the Revitalization of Meat and Meat Product Selling Business, Project No. PJ009848)," Rural Development Administration, Republic of Korea. This research was also supported by the Priority Research Centers Program through the National Research Foundation of Korea (NRF), funded by the Ministry of Education (2009-0093813).

\section{References}

[1] Cuvelier, M. E. - Berset, C. - Richard, H.: Antioxidant constituents in sage (Salvia officinalis). Journal of Agricultural and Food Chemistry, 42(3), 1994, pp. 665-669.

[2] Korimova, L. - Mate, D. - Turek, P.: The evaluation of raw fermented meat products stabilized with vitamin E and rosemary. Folia Veterinaria (Slovak Republic), 42(4), 1998, pp. 179-181.

[3] Cofrades, S. - Lopez-Lopez, I. - Solas, M. T. - Bravo, L. Jimenez-Colmenero, F.: Influence of different types and proportions of added edible seaweeds on characteristics of lowsalt gel/emulsion meat systems. Meat Science, 79(4), 2008, pp. 767-776.

[4] Hygreeva, D. - Pandey, M. C. - Radhakrishna, K.: Potential applications of plant based derivatives as fat replacers, antioxidants and antimicrobials in fresh and processed meat products. Meat science, 98(1), 2014, pp. 47-57.

[5] Froehlicher, T. - Hennebelle, T. - Martin-Nizard, F. - Cleenewerck, P. - Hilbert, J.L. - Trotin, F. - Grec, S.: Phenolic profiles and antioxidative effects of hawthorn cell suspensions, fresh fruits, and medicinal dried parts. Food Chemistry, 115(3), 2009,pp. 897-903.

[6] Lahucky, R. - Nuernberg, K. - Kovac, L. - Bucko, O. - Nuernberg, G.: Assessment of the antioxidant potential of selected plant extracts--in vitro and in vivo experiments on pork. Meat Science, 85(4), 2010, pp. 779-784.

[7] Savadkoohi, S. - Hoogenkamp, H. - Shamsi, K. - Farahnaky, A.: Color, sensory and textural attributes of beef frankfurter, beef ham and meat-free sausage containing tomato pomace. Meat science, 97(4), 2014, pp. 410-418.
[8] Biswas, A. K. - Keshri, R. C. - Bisht, G. S.: Effect of enrobing and antioxidants on quality characteristics of precooked pork patties under chilled and frozen storage conditions. Meat science, 66(3), 2004, pp. 733-741.

[9] Jayathilakan, K. - Sharma, G. K. - Radhakrishna, K. - Bawa, A. S.: Antioxidant potential of synthetic and natural antioxidants and its effect on warmed-over-flavour in different species of meat. Food Chemistry, 105(3), 2007, pp. 908-916.

[10] Chau, C. F. - Wu, S. H.: The development of regulations of Chinese herbal medicines for both medicinal and food uses. Trends in Food Science \& Technology, 17(6), 2006, pp. 313-323.

[11] Lasekan, O. - Lasekan, A.: Flavour chemistry of mate and some common herbal teas. Trends in Food Science \& Technology, 27(1), 2012, pp. 37-46.

[12] Yeung, W. F. - Chung, K. F. - Ng, K. Y. - Yu, Y. M. - Ziea, E. T. Ng, B. F.: A systematic review on the efficacy, safety and types of Chinese herbal medicine for depression. Journal of Psychiatric Research, 57, 2014, pp. 165-175.

[13] Kim, J. G. - Kang, Y. M. - Eum, G. S. - Ko, Y. M. - Kim, T. Y.: Antioxidative avtivity and antimicrobial activity of extracts from medicinal plants (Akebia quinate Decaisn,Scirusfluviatilis A. Gray, Gardenia jasminoides for. grandiflora Makino). Journal of Agriculture \& Life Sciences, 37(4), 2003, pp. 69-75.

[14] de Souza Silva, J. E. - Santos Souza, C. A. - da Silva, T. B. Gomes, I. A. - Brito, G. D. C. - de Souza Araújo, A. A. - de LyraJúnior, D. P. - da Silva, W. B. - da Silva, F. A.: Use of herbal medicines by elderly patients: A systematic review. Archives of Gerontology and Geriatrics, 59(2), 2014, pp. 227-233.

[15] Mohamed, H. M. - Mansour, H. A. - Farag, M. D.: The use of natural herbal extracts for improving the lipid stability and sensory characteristics of irradiated ground beef. Meat Science, 87(1), 2011, pp. 33-39.

[16] van Galen, E.: Traditional herbal medicines worldwide, from reappraisal to assessment in Europe. Journal of Ethnopharmacology, 158 Pt B, 2014, pp. 498-502.

[17] Kim, J. H. - Kim, J. E. - Lee, Y. K. - Nam, S. H. - Her, Y. K. - Jee, S. W. - Kim, S. G. - Park, D. J. - Choi, Y. W. - Hwang, D. Y.: The extracts from Liriope platyphylla significantly stimulated insulin secretion in the HIT-T15 pancreatic $\beta$-cell line. Journal of Life Science, 20(7),2010,pp. 1027-1033.

[18] Lee, S. K. - Park, J. H. - Kim, Y. T.: A study on the antioxidation and antimicrobial effect of "Megmoondong(Liriope platyphylla Wang et Tang)" water extracts.The Korean Journal of Food And Nutrition, 22(2), 2009,pp. 279-285.

[19] Park, S. D. - Lee, G. H. - Lee, Y. S. - Kwon, Y. K. - Park, J. H. Choi, S. M. - Shin, S. W.: Comparison of immunomodualtory effects of water-extracted Adenophorae radix, Liriopis tuber, Dendrobii herba, Polygonati Odorati phizoma and Polygonati rhizoma. Korean Journal of Oriental Physiology \&Pathology, 21(2), 2007, pp. 11.

[20] Wang, C. C. - Chen, L. G. - Yang, L. L.: Inducible nitric oxide synthase inhibitor of the Chinese herb I. Saposhnikovia divaricata (Turcz.) Schischk. Cancer Letter, 145(1-2), 1999, pp. 151-157.

[21] Wang, C. N. - Shiao, Y. J. - Kuo, Y. H. - Chen, C. C. - Lin, Y. L.: Inducible nitric oxide synthase inhibitors from Saposhnikovia divaricata and Panax quinquefolium. Planta Medica, 66(7), 2000, pp. 644-647.

[22] Han, B. J. - Woo, S. K. - Shin, H. K.: Effects of the water extract of Akebia (Akebia quinata Decaisne) on the growth of Clostridium perfringens and some intestinal microorganisms.The Korean Society for Microbiology and Biotechnology, 23(6), 1995,pp. 633640.

[23] Kwak, W. J. - Han, C. K. - Chang, H. W. - Kim, H. P. - Kang, S. S - Son, K. H.: Loniceroside C, an antiinflammatory saponin from Lonicera japonica. Chemical and Pharmaceutical Bulletin (Tokyo), 51(3), 2003, pp. 333-335.

[24] Xiang, T. - Xiong, Q. B. - Ketut, A. I. - Tezuka, Y. - Nagaoka, T. Wu, L. J. - Kadota, S.: Studies on the hepatocyte protective activity and the structure-activity relationships of quinic acid and caffeic acid derivatives from the flower buds of Lonicera bournei. Planta Medica, 67(4), 2001, pp. 322-325.

[25] Yoo, H. J. - Kang, H. J. - Song, Y. S. - Park, E. H. - Lim, C. J.: Anti-angiogenic, antinociceptive and anti-inflammatory activities of Lonicera japonica extract. Journal of Pharmcy and Pharmacology, 60(6), 2008, pp. 779-786.

[26] Yang, G. - Lee, K. - Lee, M. H. - Kim, S. H. - Ham, I. H. - Choi, H. Y.: Inhibitory effects of Chelidonium majus extract on atopic 
dermatitis-like skin lesions in NC/Nga mice. Journal of Ethnopharmacology, 138(2), 2011, pp. 398-403.

[27] Fernández-López, J. - José Angel, P. A. - Aranda-Catalá, V.: Effect of mincing degree on colour properties in pork meat. Color Research \& Application, 25(5),2000,pp. 376-380.

[28] Horwitz, W. - Latimer, G. (Ed.): Official methods of analysisof AOAC International. 18th edition. Gaithersburg AOAC International, 2005.

[29] Buege, J. A. - Aust, S. D.: Microsomal lipid peroxidation. Methods in Enzymology, 52, 1978, pp. 302-310.

[30] Pearson, D. (Ed.): The chemical analysis of foods. 7th edition. Churchill: Livingston, 1976. ISBN 0700014578.

[31] Bersuder, P. - Hole, M. - Smith, G.: Antioxidants from a heated histidine-glucose model system. I: Investigation of the antioxidant role of histidine and isolation of antioxidants by high-performance liquid chromatography. Journal of the American Oil Chemists' Society, 75(2), 1998, pp. 181-187.

[32] Cross, H. R. - Moen, R. - Stanfield, M. S.: Training and testing of judges for sensory analysis of meat quality. Food Technology, 32, 1979, pp. 48-54.

[33] SAS, Program: Windows Version 9.1. 3. 2003.SAS Institute Inc.: Cary, NC.

[34] Park, J. H. - Kang, S. N. Chu, G. M.- Jin, S. K.: Growth performance, blood cell profiles, and meat quality properties of broilers fed with Saposhnikovia divaricata, Lonicera japonica, and Chelidonium majus extracts. Livestock Science, 165, 2014, pp. 87-94.

[35] Park, J. H. - Kang, S.N. - Jin, S.K.: Effects of dietary supplementation of aqueous extracts of Liriopeplatyphylla and Akebiaquinata on breast meat qualities of broiler chickens. Korean journal for food science of animal resources, 33(4), 2013, pp. 456462.

[36] Langlois, B. E. - Kemp, J. D.: Microflora of fresh and dry-cured hams as affected by fresh ham storage. Journal of Animal Science, 38(3), 1974, pp. 525-531.

[37] Demeyer, D. I. - Vandekerckhove, P. - Moermans, R.: Compounds determining $\mathrm{pH}$ in dry sausage. Meat Science, 3(3), 1979, pp. 161167.

[38] Lim, S. D. - Kim, K. S. - Kim, H. S.: Effect of Moktong and Jimo water extracts on the growth of lactic acid bacteria. Korean Journal of Dairy Science, 21(4), 1999, pp.285-290.

[39] Han, J. - Rhee, K. S.: Antioxidant properties of selected Oriental non-culinary/nutraceutical herb extracts as evaluated in raw and cooked meat. Meat science, 70(1), 2005, pp. 25-33.

[40] Ayadi, M. A. - Kechaou, A. - Makni, I. - Attia, H.: Influence of carrageenan addition on turkey meat sausages properties. Journal of Food Engineering, 93(3), 2009, 278-283.

[41] Horita, C. N. - Messias, V. C. - Morgano, M. A. - Hayakawa, F. M. - Pollonio, M. A. R.: Textural, microstructural and sensory properties of reduced sodium frankfurter sausages containing mechanically deboned poultry meat and blends of chloride salts. Food Research International, 66(0), 2014, pp. 29-35.
[42] Yang, H. S. - Jeong, J. Y. - Lee, J. I. - Yun, I. R. - Joo, S. T. - Park, G. B.: Effects of green tea extracts on quality characteristics and reduced nitrite content of emulsion type sausage during storage. Korean Journal for Food Science of Animal Resources, 26(4), 2006, pp. 454-463.

[43] Higdon, J. V. - Frei, B.: Tea catechins and polyphenols: health effects, metabolism, and antioxidant functions. Critical Reviews in Food Science and Nutrition, 43(1), 2003, pp. 89-143.

[44] Bozkurt, H.: Utilization of natural antioxidants: Green tea extract and Thymbra spicata oil in Turkish dry-fermented sausage. Meat Science, 73(3), 2006, pp. 442-450.

[45] Nishimoto, S. I. - Hashimoto, F. - Shimizu, K.- Sakata, Y.: Petal Coloration of Interspecific Hybrids between Camellia chrysantha $\mathrm{X}$ C. japonica. Journal of the Japanese Society for Horticultural Science, 73(2), 2004, pp. 189-191.

[46] Tanikawa, N. - Kashiwabara, T. - Hokura, A. - Abe, T. - Shibata, M. - Nakayama, M.: A peculiar yellow flower coloration of camellia using aluminum-flavonoid interaction. Journal of the Japanese Society for Horticultural Science, 77(4), 2008, pp. 402407.

[47] Carpenter, R. - O'Grady, M. N. - O'Callaghan, Y. C. - O'Brien, N. M. - Kerry, J. P.: Evaluation of the antioxidant potential of grape seed and bearberry extracts in raw and cooked pork. Meat Science, 76(4), 2007, pp. 604-610.

[48] Sebranek, J. G. - Sewalt, V. J. - Robbins, K. L. - Houser, T. A.: Comparison of a natural rosemary extract and BHA/BHT for relative antioxidant effectiveness in pork sausage. Meat Science, 69(2), 2005, pp.289-296.

[49] Sekretar, S. - Schmidt, S. - Vajdak, M. - Zahradnikova, L. - Annus, J.: Antioxidative and antimicrobial effects of some natural extracts in lard. Czech Journal of Food Sciences, 22, 2004, pp. 215-218.

[50] Cai, Y. - Luo, Q. - Sun, M. - Corke, H.: Antioxidant activity and phenolic compounds of 112 traditional Chinese medicinal plants associated with anticancer. Life Science, 74(17), 2004, pp.21572184.

[51] Jongberg, S. - Torngren, M. A. - Gunvig, A. - Skibsted, L. H. Lund, M. N.: Effect of green tea or rosemary extract on protein oxidation in Bologna type sausages prepared from oxidatively stressed pork. Meat Science, 93(3), 2013, pp. 538-546.

[52] Muthukumar, M. - Naveena, B. M. - Vaithiyanathan, S. - Sen, A R. - Sureshkumar, K.: Effect of incorporation of Moringa oleifera leaves extract on quality of ground pork patties. Journal of Food Science and Technology, 51(11), 2014, pp. 3172-3180.

[53] Hayes, J. E. - Stepanyan, V. - Allen, P. - O’Grady, M. N.- Kerry, J. P.: Evaluation of the effects of selected plant-derived nutraceuticals on the quality and shelf-life stability of raw and cooked pork sausages. LWT - Food Science and Technology, 44(1), 2011, pp. 164-172.

[54] Kim, S. D. - Ku, Y. S. - Lee, I. Z. - Kim, I. D. - Youn, K. S. General components and sensory evaluation of hot water extract from Liriopis Tuber. The Korean Society of Food Science and Nutrition, 30(1), 2001, pp. 20-24. 